\title{
Penambahan Minyak Atsiri Kulit Buah Jeruk Purut Terhadap Kualitas Sabun Transparan Dari Minyak Inti Buah Ketapang
}

\author{
Murniati $^{1}$, Dedy Suhendra ${ }^{2}$, Erin Ryantin $\mathrm{G}^{3}$, Sri Seno Handayani ${ }^{4}$, Dwi Ariani ${ }^{5}$ \\ 1,2,3,4,5 Program studi Kimia, Fakultas Matematika dan IImu Pengetahuan Alam, Universitas \\ Mataram, Indonesia \\ e-mail: murniati@unram.ac.id
}

\begin{abstract}
Abstrak
Sabun transparan adalah sabun yang memiliki tampilan yang menarik dan transparan. Sabun biasanya dibuat dari trigliserida minyak nabati edible oil seperti minyak kelapa dan kelapa sawit. Salah satu bahan baku alternatif adalah minyak inti buah ketapang. Untuk meningkatkan efektifitas sabun maka perlu ditambahkan zat aktif yaitu minyak astiri kulit jeruk purut. Minyak atrisi kulit jeruk purut mengandung senyawa-senyawa yang bersifat anti bakteri dan anti virus. Penelitian ini bertujuan untuk mengetahui pengaruh penambahan konsentrasi minyak atsiri terhadap kualitas sabun transparan dari minyak inti buah ketapang sesuai standar SNI 35322016. Konsentrasi minyak astiri yang ditambahkan sebesar $0,0 \% ; 0,5 \% ; 1,0 \% ; 1,5 \% ; 2,0 \% ; 2,5 \%$ dan $3 \%$. Parameter yang diamati meliputi kadar air, total lemak, bahan tak larut dalam etanol, alkali bebas dan asam lemak bebas, kadar klorida, lemak tidak tersabunkan dan $\mathrm{pH}$. Hasil penelitian menunjukkan bahwa penambahan minyak astiri mempengaruhi kualitas dari sabun transparan tetapi masih memenuhi standar SNI 3532-2016, kecuali nilai total lemak pada konsentrasi $0 \%, 0,5 \%, 1 \%, 1,5 \%$ dan nilai lemak tak tersabunkan tidak memenuhi standar SNI 3532-2016, hal ini dapat menyebabkan penurunan daya detergensi sabun.
\end{abstract}

Kata kunci: Sabun transparan, minyak atsiri kulit jeruk purut, minyak inti buah ketapang, SNI 3532-2016.

\begin{abstract}
Transparent soap is soap that has an attractive appearance and is transparent. Soaps are usually made from triglycerides of edible oils such as coconut oil and palm oil. One of the alternative raw materials is ketapang cernel oil. To increase the effectiveness of soap, it is necessary to add an active substance, namely the essential oil of kaffir lime peel. Kaffir lime peel essential oil contains anti-bacterial and anti-viral compounds. This study aims to determine the effect of increasing the concentration of essential oils on the quality of transparent soap from ketapang cernel oil according to SNI 3532-2016. The concentration of essential oil added is 0,0\%;0,5\%; 1,0\%; 1,5\%;2,0\%;2,5\% and $3 \%$. The parameters observed included water content, total fat, matter insoluble in ethanol, free alkali and free fatty acids, chloride content, unsaponified fat and $\mathrm{pH}$. The results showed that the addition of essential oil affected the quality of transparent soap but still met the SNI 3532-2016 standards, except for the total fat value at a concentration of $0 \%, 0.5 \%, 1 \%, 1.5 \%$ and the unsaponified fat did not meet the standard SNI 3532-2016, this causes a decrease in the detergency of the soap.
\end{abstract}

Keywords : Transparent soap, the essential oil of kaffir lime peel, ketapang cernel oil and SNI 3532-2016.

*Corresponding author.

Received 2 Juli 2020; Accepted 3 Agustus 2020; Available online 15 Oktober 2020 (c) 2020 JST. All Rights Reserved 


\section{PENDAHULUAN}

Pada dua dekade terakhir muncul berbagai macam pandemi penyakit menular yang ditimbulkan oleh infeksi virus dan bakteri yang berbahaya dan telah menciptakan sejarah baru kesehatan di dunia mengingat tingkat penyebaran dan tingkat kematian atau fatality rate-nya yang cukup tinggi. Seperti SARS misalnya, memiliki case fatality rate sebesar $11 \%$, atau MERS sebesar 34,4\% (Tahrus, 2020). Adapun Jumlah korban meninggal akibat infeksi virus corona (Covid-19) di dunia sudah melampaui angka 1 juta jiwa. Indonesia sampai saat ini telah mencapai lebih dari 10 ribu jiwa (WHO, 2020).

Dengan tingginya angka kematian yang diakibat oleh penyakit menular, pemerintah terus menggalakkan program pencegahan salah satunya adalah mencuci tangan menggunakan sabun. Hal ini menyebabkan kebutuhan sabun mengalami peningkatan yang cukup drastis yaitu pada bulan Februari sebesar 304\% dan bulan Maret 2020 sebesar $355 \%$ (Rohmah, 2020).

Sabun merupakan garam alkali karboksilat (RCOONa). Gugus R bersifat hidrofobik karena bersifat nonpolar dan COONa bersifat hidrofilik (polar) (Sari et al., 2019). Bahan dasar pembuatan sabun adalah trigliserida yang berasal dari minyak. Trigliserida yang umum digunakan sebagai bahan baku pembuatan sabun memiliki asam lemak dengan panjang rantai karbon antara 12 sampai 18 (Shinthia, 2016). Jenis minyak yang sering digunakan oleh industri-industri sebagai bahan dasar pembuatan sabun adalah minyak kelapa murni (Ismanto et al., 2016) dan kelapa sawit (Widyasanti dkk, 2016), padahal pemanfaatan terbesarnya sebagai minyak pangan. Salah satu sumber bahan baku alternatif untuk produksi sabun yang keseterdiaannya melimpah adalah minyak inti buah ketapang (Terminalia catappa Linn).

Ketapang merupakan salah satu tanaman yang dapat menghasilkan minyak dari inti buah dengan kadar tinggi, yaitu $54,4 \%$ (Suhendra \& Gunawan, 2010). Kandungan dari minyak inti buah ketapang yakni asam palmitat (35,63\%), asam oleat $(33,49 \%)$, asam linoleat $(24,29 \%)$ dan asam stearat (4,66\%) (Rahmaniar, 2013). Beberapa kandungan dari minyak inti buah ketapang memiliki manfaat yang baik bagi kulit. Menurut Husna (2012), asam oleat dan linoleat dapat membentuk lapisan tipis diatas permukaan kulit untuk mengurangi penguapan air dari kulit sehingga kelembaban kulit tetap terjaga. (El-Wathan, 2011), telah melakukan penelitian pembuatan sabun menggunakan minyak inti buah ketapang. Sabun yang dihasilkan memenuhi standar SNI dan aman digunakan untuk kulit, namun tanpa adanya penambahan bahan aktif.

Pada umumnya, sabun yang sering digunakan adalah sabun padat biasa. Namun, tampilan dari sabun transparan lebih menarik daripada sabun biasa. Sabun transparan memiliki tampilan yang transparan dan lebih berkilau dibandingkan sabun biasa serta mampu menghasilkan busa yang lembut di kulit (Widyasanti \& Hasna 2016). Selain itu, sabun transparan banyak dijual dengan harga mahal dan dapat dijadikan cinderamata dan souvenir yang unik (Widyasanti \& Hasna 2016). Keragaman sabun yang dijual secara komersial terlihat pada jenis, wangi, warna dan manfaat yang ditawarkan (Chan, 2016).

Semua jenis sabun tersebut berbeda manfaatnya berdasarkan perbedaan formulasi bahan yang digunakan dalam pembuatan. Salah satu bahan tambahan pada sabun adalah bahan aktif sintetik banyak disorot saat ini adalah triklosan yangmerupakan bahan antiseptik yang dikembangkan pertama kali pada tahun 1960dan telah digunakan dalam berbagai produk kesehatan. Sabun mengandung triklosan lebih efektif membunuh baketri dan virus yang menempel di kulit dibandingkan sabun biasa (Marhamah et al., 2019). Namun penggunaan triklosan cenderung membuat kulit tangan kering dan rentan terkena dermatitis kontak iritan atau alergi. Penggunaan triklosan terlalu sering juga dapat membunuh flora normal kulit yang seharusnya merupakan perlindungan kulit. Dilihat dari dampak 
negatif yang ditimbulkan oleh triklosan, maka perlu bahan alternatif lain yang dapat menggantikan triklosan sebagai antiseptik, salah satunya adalah minyak atsiri kulit jeruk purut.

Minyak jeruk purut Indonesia hasil penyulingan uap ranting, daun dan kulit buah tersusun atas 29 senyawa dengan komponen utama sitronelal mencapai 46,85 - 80,4\% (Warsito, et al., 2013). Minyak atsiri kulit buah jeruk purut mengandung beberapa komponen utama seperti $\beta$-pinene $(21,44 \%)$, sitronelal $(20,91 \%)$, limonene $(12,59 \%)$, dan terpinen-4-ol (11,93\%) (Warsito, 2017). $\beta$ pinene dan limonene merupakan senyawa monoterpen. Komponen- minyak atsiri seperti $\alpha$-pinene, $\beta$-pinene, dan transkaryopilen mampu menghambat bakteri Escherichia coli dan Staphylococcus aureus (Astani dan Schnitzler, 2014). Selain itu komponen $\alpha$-pinene, kamfena, dan $\beta$-linalool dapat menghambat bakteri Pseudomonas aeruginosa, Salmonella typhi, dan Bacillus cereus (Respati, 2010). $\beta$-pinene dan limonene dapat mengurangi infektifitas virus sebesar $100 \%$. Monoterpen menunjukkan aktivitas antiHSV-1 yang tinggi dengan interaksi langsung dengan partikel virus bebas (Astani \& Schnitzler, 2014). Selain itu $\beta$ pinen juga memiliki aktivitas melawan infeksi virus bronkhitis (Yang et al., 2011). Adanya kandungan minyak atsiri dalamkulit jeruk purut serta potensinya sebagai anti baketri dan anti virus memungkinkan untuk meningkatkan nilai ekonomis limbah kulit jeruk purut sebagai bahan tambahan pada pembuatan sabun, serta untuk meningkatkan kualitas dan efektifitas dari sabun.

Penambahan zat aktif dapat mempengaruhi kualitas sabun transparan. Kualitas sabun transparan meliputi kadar air, total lemak, bahan tak larut dalam etanol, alkali bebas dan asam lemak bebas, kadar klorida, dan lemak tidak tersabunkan (BSN, 2016) dan pH. Ismanto dkk (2016), melakukan penambahan minyak gaharu pada sabun VCO hasilnya menunjukkan bahwa penambahan minyak gaharu berpengaruh nyata terhadap jumlah total asam lemak dan alkali bebas/asam lemak bebas begitu juga dengan (Widyasanti et al., 2016) penambahan ekstrak daun teh putih pada sabun padat transparan dari minyak kelapa sawit dapat menyebabkan kadar lemak total tidak memenuhi standar. Oleh sebab itu, pada penelitian ini dilakukan kajian pengaruh penambahan konsentrasi minyak atsiri kulit buah jeruk purut sebagai bahan aktif pada sabun transparan terhadap kualitas sabun transparan.

\section{METODE \\ Bahan dan alat penelitian}

Bahan-bahan yang digunakan adalah buah ketapang, buah jeruk purut, dan bahan-bahan yang bersifat pro-analysis seperti etanol $96 \%, \mathrm{KOH} 0,1 \mathrm{~N}, \mathrm{NaOH} 30 \%$, $\mathrm{HCl} 10 \%, \mathrm{H}_{2} \mathrm{SO}_{4} 30 \%, \mathrm{NaCl}$ jenuh, dietil eter, $\mathrm{CCl}_{4}$, larutan wijs, indikator fenolftalein, $\mathrm{Na}_{2} \mathrm{~S}_{2} \mathrm{O}_{3} \quad 0,1 \mathrm{~N}$, asam sterat, asam sitrat, larutan $\mathrm{KI} 20 \%$, gliserin, sukrosa, indikator metil jingga, larutan kanji, batu didih, dan aquades. Alat-alat yang digunakan dalam penelitian ini adalah peralatan gelas, rotary evaporator, alat soklet, alat refluks, alat shaker, magnetik stirer, waterbath stirrer, timbangan analitik, dan cetakan sabun.

\section{Ekstraksi Minyak Inti Buah Ketapang}

Sebanyak $10 \mathrm{Kg}$ buah ketapang yang sudah disortir diambil bijinya dengan cara dibelah secara melintang. Biji yang diperoleh ditimbang, setelah itu diblender sampai halus dan hasilnya ditimbang lagi.Ekstraksi minyak ketapang dilakukan dengan metode ekstraksi maserasi. Biji ketapang yang telah diblender dimaserasi dengan pelarut $n$-heksana selama 48 jam sambil digojog dengan alat shaker pada kecepatan 150 rpm. Campuran minyak yang didapat kemudian ditampung di dalam erlenmeyer $1000 \mathrm{~mL}$. Maserat dipisahkan dengan residu dengan cara filtrasi kemudian diuapkan untuk menghilangkan n-heksana dengan rotary evaporator pada suhu $40^{\circ} \mathrm{C}$ dengan kecepatan $90 \mathrm{rpm}$. 


\section{Pembuatan minyak atsiri dari kulit jeruk purut}

Pembuatan minyak atsiri dari kulit buah jeruk purut dilakukan dengan metode yang dikembangkan (Muhtadin et al., 2013) dengan modifikasi. Ditimbang kulit jeruk purut segar yang sudah dipotong-potong kecil sebanyak 300 gr. Kemudian dimasukkan kulit jeruk purut yang ke labu destilasi uap. Dimasukkan air pada pada labu steam generator dan mulai dipanaskan. Dipanaskan labu ekstraktor ketika uap dari steam generator mulai terbentuk, kemudian ditunggu sampai tetes pertama keluar dari kondensor dan dihitung waktu ekstraksi sampai dengan variabel waktu yang ditentukan. Setelah proses ekstraksi dipisahkan minyak dari air dengan menggunakan corong pemisah, kemudian minyak ditampung pada tabung reaksi. Disimpan tabung reaksi yang berisi minyak atsiri ke dalam freezer (suhu $0{ }^{\circ} \mathrm{C}$ ) untuk mendapatkan minyak yang bebas dari air. Kemudian diambil minyak yang bebas dari air dengan pipet dan dipindahkan ke botol sampel. Kemudian minyak atsiri yang sudah diperoleh ditimbang. Hasil minyak atsiri yang diperoleh dilakukan identifikasi menggunakan GC-MS.

\section{Pengaruh konsentrasi minyak astiri terhadap kualitas sabun dari minyak inti buah ketapang}

Metode yang digunakan dalam pembuatan sabun ini sesuai dengan metode pembuatan sabun yang dikembangkan oleh (Anggraini et al., 2015) dengan beberapa modifikasi. Sebanyak 30 gr minyak inti buah ketapang hasil ekstraksi sebelumnya dimasukkan kedalam erlenmeyer $250 \mathrm{~mL}$ kemudian dipanaskan dalam penangas air sambil diaduk dengan magnetic stirer. Kemudian tuang minyak yang telah mendidih kedalam $5 \mathrm{gr}$ asam stearat yang telah meleleh serta tambahkan 0,3 gr asam sitrat dan aduk hingga homogen. Lalu dengan hati-hati ditambahkan $10 \mathrm{~mL} \mathrm{NaOH} 30 \%$ dan $30 \mathrm{~mL}$ etanol. Campuran terus dipanaskan sambil diaduk dengan kecepatan sedang sampai semua lemak tersabunkan (ditandai dengan tidak adanya lapisan minyak yang tidak bercampur ketika pengadukan dihentikan. Campuran sabun kemudian ditambahkan $15 \mathrm{~mL}$ gliserin, $5 \mathrm{gr}$ sukrosa dalam $5 \mathrm{ml}$ aquades, dan minyak atsiri kulit jeruk purut dengan variasi konsentrasi yaitu $0,5 \% ; 1 \% ; 1,5 \% ; 2 \% ; 2,5 \%$ dan $3 \%$ sambil terus diaduk sampai mengental. Setelah semuanya homogen, campuran dimasukkan dalam cetakan dan didiamkan sampai kering. Selanjutnya dilakukan uji kualitas sabun mandi yang dihasilkan sesuai dengan SNI 3532-2016.

\section{HASIL DAN PEMBAHASAN Minyak Inti Buah Ketapang}

Sampel yang digunakan pada penelitian ini adalah buah ketapang yang diperoleh dari tanaman ketapang yang ada di sekitaran wilayah kampus Universitas Mataram dan Kabupaten Lombok Barat, Provinsi Nusa Tenggara Barat.

Tabel 1. Sifat fisika kimia minyak inti buah ketapang

\begin{tabular}{cccc}
\hline No & Parameter & Nilai & Satuan \\
\hline 1 & Warna & Kuning bening & - \\
2 & Bau & Khas & - \\
3 & Rendemen & 58,75 & $\%$ \\
4 & Bilangan asam & 2,40 & $\mathrm{mgNaOH} / \mathrm{gram}$ \\
5 & Bilangan penyabunan & 245,43 & $\mathrm{mgKOH} / \mathrm{gram}$ \\
6 & Bilangan lod & 92,01 & $\mathrm{mg} \mathrm{iod} / 100 \mathrm{gr}$ \\
\hline
\end{tabular}

Minyak yang diperoleh berwarna kuning bening dengan rendemen 58,75\%. Kadar minyak yang diperoleh, lebih tinggi dibandingkan kadar minyak yang diperoleh
(Gunawan et al., 2018) sebesar 56,4\%. Persen yield maksimum yang diperoleh dari minyak ketapang dengan metode soxhletasi adalah sebesar $54,22-60,45 \%$ 
(Janporn et al., 2015; Menkiti et al., 2015). Bilangan asam yang diperoleh pada peneltian ini sesuai dengan bilangan asam menurut SNI 2015 yaitu maks 4,0 $\mathrm{mgNaOH} / \mathrm{gram}$. Bilangan penyabunan diperoleh sebesar 245,43 $\mathrm{mgKOH} / \mathrm{gram}$. Nilai bilangan penyabunan yang diperoleh sesuai dengan nilai bilangan penyabunan menurut SNI 2015 yaitu 180-265 $\mathrm{mgKOH} / \mathrm{gram}$. Bilangan iod dari minyak inti buah ketapang adalah sebesar 92,01 mg iod/100gr yang berarti minyak inti buah ketapang mengandung asam lemak tak jenuh dengan jumlah yang aman untuk dijadikan bahan dasar pembuatan sabun, karena SNI untuk bilangan iod tidak boleh lebih dari $115 \mathrm{mgiod} / 100 \mathrm{gr}$.

\section{Minyak atsiri kulit buah jeruk purut}

Minyak atsiri memiliki bentuk cair, berwarna bening, dan berbau khas kulit buah jeruk purut yang kuat. Minyak atsiri yang dihasilkan sebanyak 6,41 gram dari 183 gram kulit buah jeruk purut utuh yang diekstraksi. Rendemen minyak atsiri kulit buah jeruk purut yang diperoleh sebesar $3,50 \%$. Hasil penelitian menunjukkan rendemen minyak atsiri kulit buah jeruk purut lebih besar dari penelitian (Muhtadin et al., 2013), minyak atsiri hasil destilasi uap kulit buah jeruk purut utuh selama 3 jam menghasilkan rendemen sebesar 1,6 $\%$.

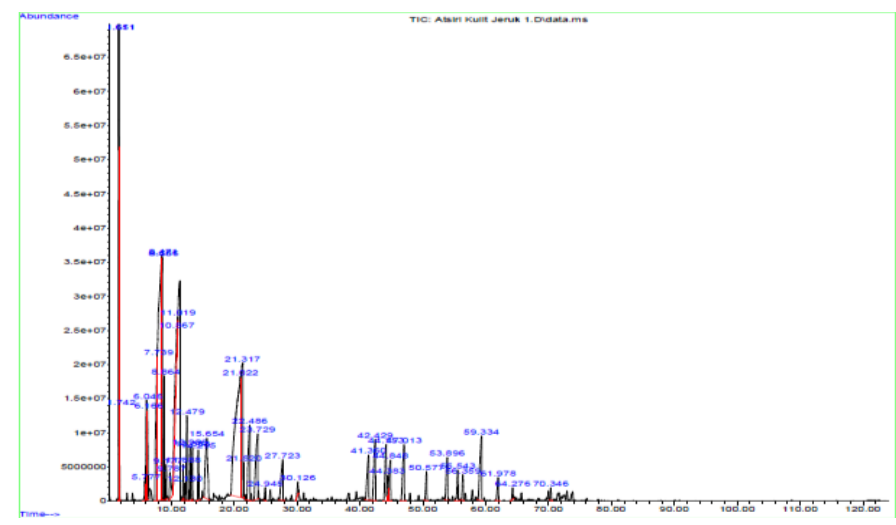

Gambar 1. Kromatogram hasil GC-MS minyak atsiri kulit buah jeruk purut

Berdasarkan hasil GC-MS pada gambar 1 menunjukkan bahwa minyak atsiri kulit buah jeruk purut terdiri dari 42 puncak senyawa dengan 8 puncak senyawa mayor yaitu $\alpha$-pinene, $\beta$ terpinene, $\beta$-pinene, limonene, linalool, citronellal, terpinen-4-ol dan a-terpineol. Senyawa aktif utama yang ditemukan pada penelitian ini dengan luas area yang cukup tinggi yaitu a-pinene sebesar $18,99 \%$ pada waktu retensi 8,451 menit dan sitronelal dengan luas area $15,44 \%$ pada waktu retensi 21,022 menit. Kedua senyawa tersebut merupakan senyawa yang memiliki luas area yang cukup tinggi dibandingkan dengan senyawa lain

\begin{abstract}
Pengaruh Konsentrasi Minyak Atsiri Kulit Buah Jeruk Purut terhadap Sabun Transparan dari Minyak Inti Buah Ketapang
\end{abstract}

\section{Kadar Air}

Kadar air merupakan air yang terkandung di dalam sabun. Pengujian kadar air pada sabun perlu dilakukan karena kadar air akan mempengaruhi tingkat kekerasan dan kualitas sabun. Apabila kandungan air pada sabun terlalu tinggi akan menyebabkan sabun mudah menyusut dan tidak nyaman saat digunakan. (Rita, 2018), menyatakan bahwa semakin tinggi kadar air sabun maka sabun akan semakin lunak, sebaliknya semakin rendah kadar air sabun 
maka sabun akan semakin keras. dalam sediaan sabun mandi padat Berdasarkan SNI 3532-2016, kadar air maksimal 15\%.

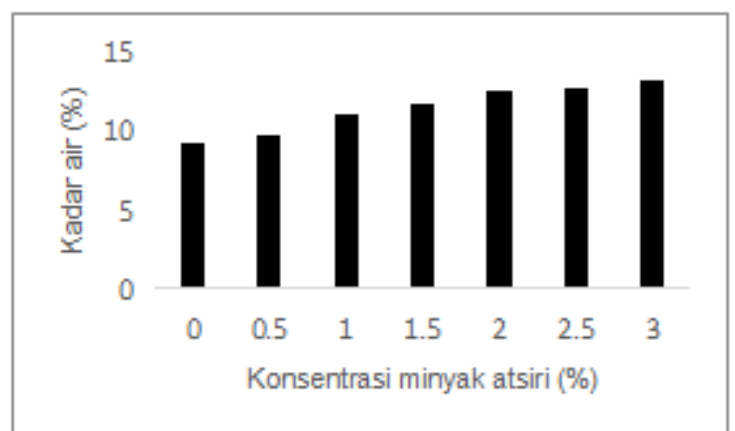

Gambar 2. Pengaruh konsentrasi terhadap kadar air

Dari grafik pada gambar 2 diatas menunjukkan bahwa semakin tinggi konsentrasi minyak atsiri maka semakin tinggi pula kadar air pada sabun transparan. Hal ini disebabkan karena adanya kandungan air yang terdapat dalam minyak atsiri ketika proses destilasi yang mengakibatkan semakin banyak volume minyak atsiri yang ditambahkan pada sabun maka semakin banyak pula kandungan air dalam sabun. Kadar air tertinggi terdapat pada konsentrasi 3\% sebesar 13,21\%. Hasil kadar air sabun pada penelitian ini sesuai dengan standar SNI 3532-2016. (Qisti, 2009), sabun transparan memiliki kadar air yang lebih besar dibandingkan sabun mandi biasa disebabkan $\mathrm{Hal}$ ini dapat disebabkan karena adanya penambahan bahan yang memiliki sifat higroskopis yaitu menyerap air yang berada di udara seperti gliserin, larutan gula, dan etanol. Penambahan bahan-bahan tersebut diduga mengakibatkan sabun menjadi mudah menyerap uap air dari udara sehingga menghasilkan kadar air yang lebih tinggi (Marpaung et al., 2019).

\section{Total lemak}

Total lemak merupakan jumlah keseluruhan asam lemak yang berada didalam sabun, baik itu yang tersabunkan maupun yang tidak. Total lemak yang diperoleh pada penelitian ini mengalami kenaikan setelah penambahan variasi konsentrasi minyak atsiri kulit buah jeruk purut (Citrus Hystrix DC.) pada sabun. Nilai total lemak sabun dapat dilihat pada gambar 3 dibawah ini.

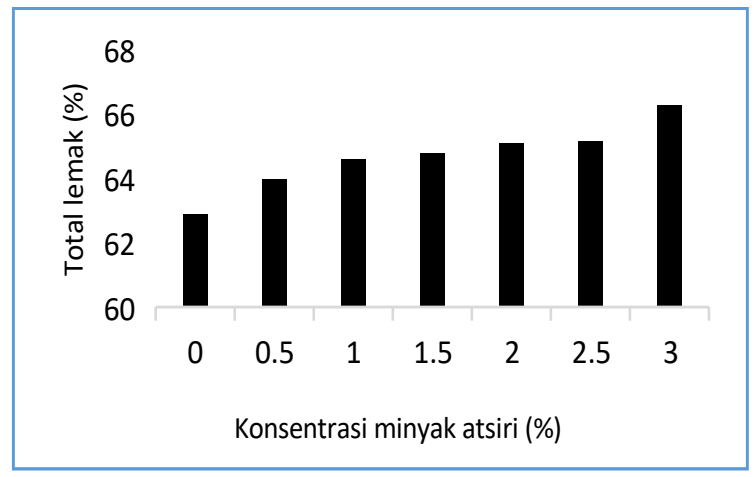

Gambar 3. Pengaruh konsentrasi terhadap total lemak. 
Berdasarkan grafik pada gambar 3 menjukkan bahwa semakin tinggi penambahan konsentrasi minyak atsiri kulit buah jeruk purut, maka nilai total lemak sabun semakin tinggi. Hal ini diduga karena minyak atsiri termasuk dalam golongan senyawa organik monoterpen seperti limonene dan a-pinene, juga alkohol terpen seperti linalool dan sitronellol yang memiliki sifat larut dalam lemak atau minyak (Ramadani, 2016), sehingga penambahan minyak atsiri dapat meningkatkan total lemak pada sabun. Hasil uji total lemak yang sesuai dengan mutu SNI 35322-2016 yaitu pada penambahan konsentrasi $2 \%, 2,5 \%$ dan $3 \%$ dengan nilai total lemak masing-masing melebihi standar minimal.

\section{Bahan tak larut dalam etanol}

Bahan tak larut dalam etanol pada sabun meliputi garam alkali seperti karbonat, silikat, fosfat, sulfat dan pati (Hernani et al., 2010). Hasil bahan tak larut dalam etanol pada sabun transparan dengan penambahan minyak atsiri kulit buah jeruk purut memenuhi standar SNI 3532-2016 yaitu maksimal 5,0\%. Data bahan tak larut dalam etanol dapat dilihat pada grafik gambar 4 berikut ini.

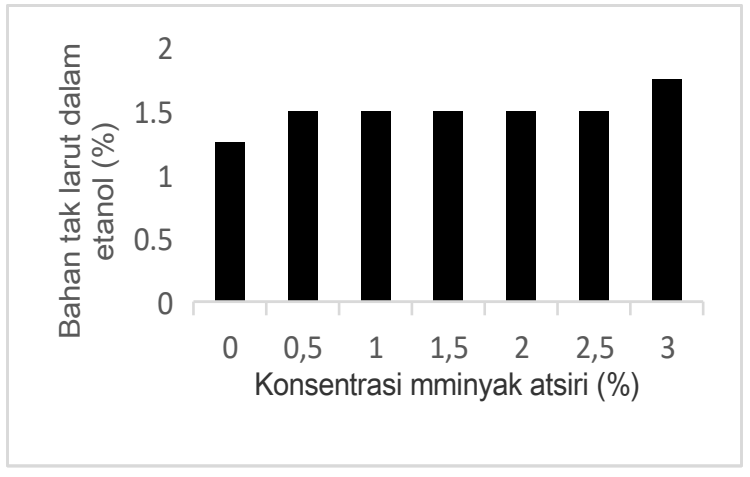

Gambar 4. Pengaruh konsentrasi terhadap bahan tak larut dalam etanol.

Nilai bahan tak larut dalam etanol sabun transparan tertinggi yaitu pada penambahan konsentrasi minyak atsiri 3\% yaitu sebesar 1,75\% dengan nilai bahan tak larut dalam etanol terendah terdapat pada sabun yang tidak mengandung penambahan minyak atsiri yaitu $1,25 \%$. Semakin mudah larut minyak dalam etanol maka semakin banyak kandungan senyawa polar dalam minyak (Susetyo \& Reny, 2004). Alkohol merupakan gugus hidroksil $(\mathrm{OH})$, karena itu alkohol dapat larut dengan minyak atsiri. Pada umumnya minyak atsiri yang mengandung senyawa terpen teroksigenasi lebih mudah larut dalam alkohol dari pada yang mengandung terpen tak teroksigenasi. Semakin tinggi kandungan terpen tak teroksigenasi maka semakin sukar larut dalam etanol (pelarut polar), karena senyawa terpen tak teroksigenasi merupakan senyawa non polar yang tidak memiliki gugus fungsional.
Hal ini menyebabkan seiring dengan penambahan minyak atsiri yang semakin besar kelarutan minyak atsiri pada etanol maka kualitas minyak atsiri semakin baik (Susetyo \& Reny, 2004).

\section{Asam lemak bebas atau alkali bebas}

Asam lemak bebas adalah asam lemak yang berada dalam sampel sabun, tetapi tidak terikat sebagai senyawa natrium maupun senyawa trigliserida. Asam lemak yang masih ada pada sabun disebabkan tidak mengalami reaksi penyabunan. Asam lemak bebas yang baik dalam sabun adalah maksimal 2,5\% (SNI 3532-2016). Uji ini dilakukan untuk mengetahui adanya kelebihan asam lemak bebas atau alkali bebas. Hal ini dapat ketahui berdasarkan Standar Nasional Indonesia 3532-2016, ketika melakukan uji terdapat penambahan indikator fenolftalein pada sampel, jika larutan sampel saat 
penambahan fenolftalein tidak berwarna maka terjadi kelebihan asam lemak bebas, dan sebaliknya jika penunjuk fenolftalein ketika ditambahkan pada larutan menjadi warna merah maka menunjukkan adanya alkali bebas berlebih. Hasil analisis penelitian ini menunjukkan adanya asam lemak bebas berlebih. Gambar 5 menunjukkan pengaruh penambahan minyak atsiri terhadap asam lemak bebas dalam sabun.

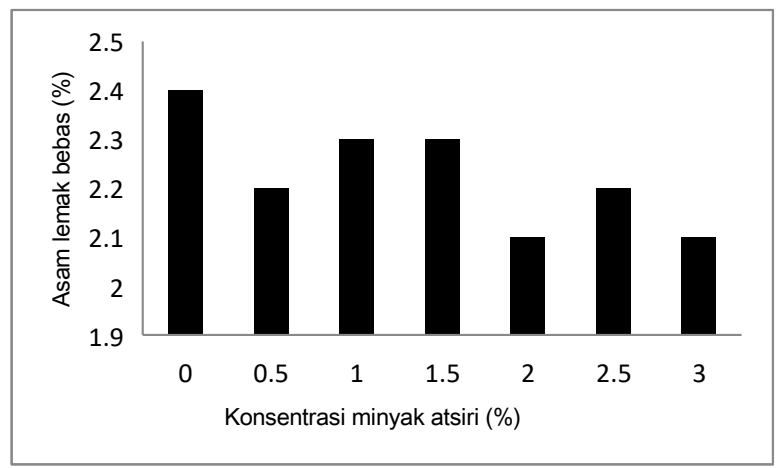

Gambar 5. Pengaruh minyak atsiri terhadap asam lemak bebas.

Berdasarkan hasil uji asam lemak bebas secara keseluruhan mengalami penurunan yang tidak signifikan seiring dengan penambahan konsentrasi minyak atsiri kulit buah jeruk purut. Hal ini menunjukkan bahwa penambahan minyak atsiri tidak berpengaruh terhadapkadar asam lemak bebas. Asam lemak bebas tertinggi terdapat pada konsentrasi $0 \%$ dengan nilai $2,4 \%$. Asam lemak bebas yang ada dalam sabun merupakan asam lemak yang terbentuk dari proses ekstraksi minyak inti buah ketapang dan tidak bereaksi saat reaksi penyabunan. Hal ini menandakan kurangnya kandungan alkali dalam sabun sehingga tidak mampu membentuk reaksi penyabunan yang baik dengan asam lemak. Hasil uji asam lemak bebas ini memenuhi nilai mutu SNI 35322016.

\section{Kadar Klorida}

Penentuan kadar klorida bertujuan untuk mengetahui banyaknya kandungan klorida di dalam sabun. Kadar klorida kemungkinan dapat berasal dari air keran yang digunakan sebagai pelarut. Pada penelitian ini pelarut yang digunakan adalah akuades. Selain itu, kadar klorida juga dapat berasal dari bahan yang digunakan dalam pembuatan sabun seperti garam dapur yang dapat berfungsi untuk memperkeras struktur sabun. Akan tetapi, penelitian ini tidak menggunakan bahan yang mengandung klor, sehingga hasil yang didapatkan bersifat negatif (-) terhadap kadar klorida.

\section{Lemak Tak Tersabunkan}

Lemak tak tersabunkan adalah asam lemak yang larut dalam minyak, tetapi tidak dapat membentuk sabun dengan alkali. Daya detergensi sabun berkurang dapat disebabkan oleh banyaknya lemak tak tersabunkan (Rita, 2018). Hasil penelitian lemak tak tersabunkan ini tidak memenuhi SNI 3532-2016 sabun yaitu maksimal 0,5\% 


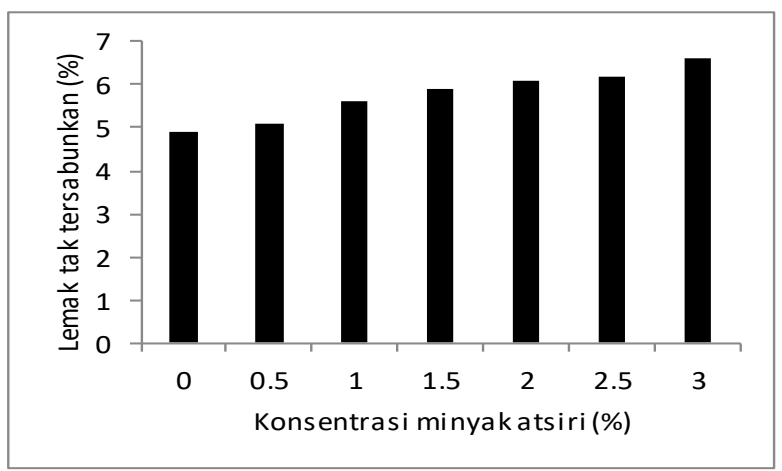

Gambar 6. Pengaruh minyak atsiri terhadap lemak tak tersabunkan.

Hasil penelitian pada grafik gambar 6 menunjukkan terjadinya kenaikan lemak tak tersabunkan seiring penambahan konsentrasi minyak atsiri kulit buah jeruk purut. Lemak tak tersabunkan merupakan zat-zat yang dapat berupa sterol, zat warna, dan hidrokarbon. Pada konsentrasi $3 \%$ dihasilkan lemak tak tersabunkan dengan nilai $6,6 \%$. Semakin tinggi penambahan konsentrasi minyak atsiri maka lemak tak tersabunkan semakin meningkat. Hal ini disebabkan ketika reaksi penyabunan terdapat asam lemak berlebih setelah penambahan minyak atsiri sehingga menyebabkan asam lemak dengan alkali tidak habis bereaksi yang menyebabkan lemak tak tersabunkan relatif tinggi dan tidak memenuhi syarat mutu SNI 3532-2016. Selain itu, minyak atsiri juga memiliki sifat tidak bisa tersabunkan dengan alkali (Ismanto et al., 2016) sehingga semakin banyak penambahan konsentrasi minyak atsiri pada sabun maka lemak tak tersabunkan akan semakin meningkat.

pH

Uji pH atau derajat keasaman bertujuan untuk mengetahui sabun yang dihasilkan bersifat asam atau basa. Kulit normal memiliki pH sekitar 5. Mencuci dengan sabun dapat meningkatkan nilai $\mathrm{pH}$ kulit sementara. Menurut (Wasitaatmadja, 2007) sabun yang memiliki nilai $\mathrm{pH}$ yang sangat tinggi atau sangat rendah dapat menambah daya absorbansi kulit sehingga memungkinkan kulit mengalami iritasi.

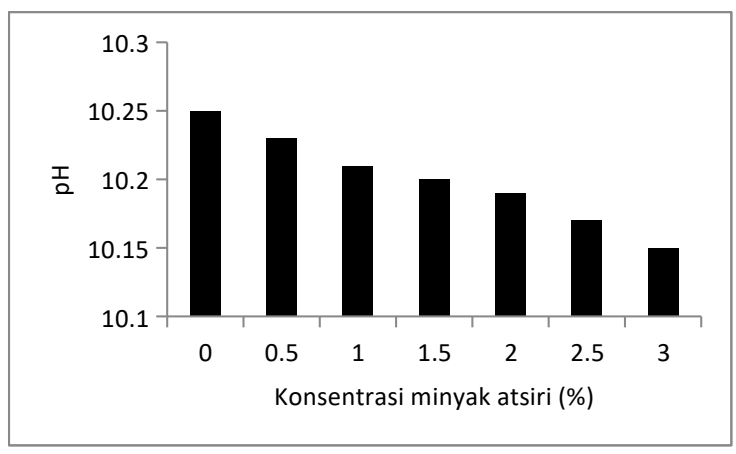

Gambar 7. Pengaruh penambahan minyak atsiri terhadap pH

Berdasarkan grafik pada gambar 7 , nilai $\mathrm{pH}$ sabun transparan yang diperoleh berkisar antara 10,15 - 10,25. Nilai $\mathrm{pH}$ tersebut masih termasuk dalam kisaran sabun untuk kulit yaitu antara 9-11(Hernani et al., 2010). Nilai pH sabun cenderung 
menurun seiring dengan bertambahnya konsentrasi minyak atsiri kulit buah jeruk purut. Menurut (Febrianti, 2013), hal ini disebabkan minyak atsiri kulit buah jeruk purut bersifat asam sehingga dapat menurunkan $\mathrm{pH}$ sabun. Oleh karena itu, semakin banyak penambahan konsentrasi minyak atsiri maka $\mathrm{pH}$ sabun akan semakin menurun.

\section{SIMPULAN}

Penambahan minyak atsiri dapat mempengaruhi kualitas pada sabun transparan. Kualitas sabun transparan memenuhi standar SNI 3532-2016, kecuali untuk nilai total lemak pada dan nilai lemak tak tersabunkan.kecuali nilai total lemak pada konsentrasi $0 \%, 0,5 \%, 1 \%, 1,5 \%$ dan nilai lemak tak tersabunkan tidak memenuhi standar SNI 3532-2016.

\section{UCAPAN TERIMAKASIH}

Ucapan terimakasih disampaikan kepada pihak Universitas Mataram atas pendanaan penelitian ini melalui sumber dana DIPA BLU skema Penelitian Dosen Pemula dengan No. Kontrak 2489Q/UN18.L1/PP/2019.

\section{DAFTAR PUSTAKA}

Anggraini, T., Sahadi, D. I., dan Dahlia. 2015. The Making of Transparent Soap From Green Tea Extract. Journal on Advanced Science Engineering Information Technology. Vol.5, No. 4.

Astani, A dan Schnitzler, P. 2014. Antiviral Activity of Monoterpenes Beta-pinene and Limonene Against Herpes Simplex Virus In Vitro. Journal of Microbiology. Vol. 6 (3). 149-155.

BSN. 2016. SNI 3532:2016. Sabun Mandi Padat. Jakarta: Dewan Standardisasi Nasional.

Chan, A. (2016). Formulasi Sediaan Sabun Mandi Padat Dari Ekstrak Buah Apel (Malus Domesticus) Sebagai Sabun Kecantikan Kulit. Jurnal IImiah Manuntung. Halaman 51-52.
Dyartanti, E. R., N. A. Cristi dan I. Fauzi. 2014. Pengaruh Penambahan Minyak Sawit Pada Karakteristik Sabun Transparan. Jurnal EKUILIBRIUM. 13 (2): 41-44.

El-Wathan, L. S. H. 2011. Pembuatan Sabun Mandi dari Minyak Inti Buah Ketapang (Terminalia catappa L.) dengan Metode Saponifikasi. Program studi Kimia Fakultas MIPA Universitas Mataram.

Febrianti, D. R. 2013. Formulasi Sediaan Sabun Mandi Cair Minyak Atsiri Jeruk Purut (Citrus Hystrix DC.) dengan Kokamidopropil Betain sebagai Surfaktan. Surakarta: Universitas Muhammadiyah Surakarta

Gunawan, E. R., Dedy, S., Ipan, H., dan Lely, K. 2018. Optimization Of Alkyldiethanolamida Synthesis From Terminalia catappa L. Kernel Oil through Enzymatic Reaction. Journal of Oleo Science. 67 (8) 949-955

Hernani, Titik, K. B., dan Fitriati. 2010. Formula Sabun Transparan Antijamur dengan Bahan Aktif Ekstrak Lengkuas (Alpinia Galangal L.Swartz). Bul. Littro. Vol. 21 No. 2, $192-205$

Husna, N., Suryanto, Djendakita, P. 2012. Efek Pelembab Minyak Biji Bunga Matahari dalam Sediaan Krim Tangan. Journal Of Pharmaceutics And Pharmacology. Vol. 1 (1): 63-69.

Ismanto, S. D., Neswati, dan Selviorizal, A. 2016. Pembuatan Sabun Aromaterapi dari Minyak Kelapa Murni (Virgin Coconut Oil) dengan Penambahan Minyak Gubal Gaharu (Aquilaria Malaccemsis). Jurnal Teknologi Pertanian Andalas. Vol. 20, No. 2.

Janporn, S., Chi-Tang, H., Visith, C., MinHsiung, P., Sasivimon, C., Khanitta, R., dan Monthana W. 2015. Physicochemical Properties of Terminalia catappa Seed Oil as a Novel Dietary Lipid Source. J. Food 
Drug Anal. 23, 201-209. https://doi.org/10.1016/j.jfda.2014.06. 007.

Marhamah, Sri Ujiani, Maria Tuntun. 2019. Kemampuan Sabun Antiseptik Cair yang Mengandung Triclosan yang Terdaftar di BPOM dalam Menghambat Pertumbuhan Bakteri Escherichia coli. Jurnal Kesehatan. Volume 10, Nomor 1, April 2019, hlm 17-24

Marpaung, JJA, Dewi Fortuna Ayu, dan Raswen Efendi. 2019. Sabun transparan Berbahan Dasar Minyak Kelapa Murni dengan Penambahan Ekstrak Daging Buah Pepaya. Jurnal Agroindustri Halal. Volume 5 Nomor 2, 161.

Menkiti, M.C., Agu, C.M., Udeigwe, T.K. 2015. Extraction of oil from Terminalia catappa L.: Process parameter impacts, kinetics, and thermodynamics. Industrial Crops and Products. 77 (2015) 713-723. Journal homepage: www.elsevier.com/locate/indcrop

Muhtadin, A. F., Ricky, W., Pantjawarni, P., dan Mahfud. 2013. Pengambilan Minyak Atsiri dari Kulit Jeruk Segar dan Kering dengan Menggunakan Metode Steam Distillation. Jurnal Teknik Pomits. Vol. 2, No. 1.

Oluwatoyin, S. M. 2011. Quality of Soaps Different Oil Blends. J. Microbiol. biotech. res. Vol. 1(1): 29-34.

Qisti, Rachmiati. 2009. Sifat Kimia Sabun Transparan dengan Penambahan Madu pada Konsentrasi yang Berbeda. Bogor. Program Studi Teknologi Hasil Ternak Fakultas Peternakan, Institut Pertanian Bogor.

Rahmaniar. 2013. Minyak Biji Ketapang (Terminalia catappa L) Sebagai Bahan Pelunak dalam Pembuatan Kompon Karet. Jurnal Dinamika Penelitian Industri. 24(1), p: 49-56.
Ramadani, R. 2016. Senyawa Kimia Bahan Alam Terpenoid. e-Journal IAIN Kerinci. Vol. 1 No.1.

Respati, N. W. B. 2010. Isolasi, Identifikasi dan Uji Aktivitas Antibakteri Minak Atsiri Rimpang Lempuyang Wangi. Fakultas Matematika dan IImu Pengetahuan Alam. Universitas Sebelas Maret Surakarta.

Rita, W. S., Vinapriliani, N. P. E., dan Gunawan, I. W. G. 2018. Formulasi Sediaan Sabun Padat Minyak Atsiri Serai Dapur (Cymbopogon citratus DC.) Sebagai Antibakteri terhadap Escherichia coli dan Staphylococcus aureus. Cakra Kimia. 6(2), 152-160.

Rohmah, S. N. 2020. Adakah Peluang Bisnis di Tengah Kelesuan Perekonomian Akibat Pandemi Coronavirus Covid-19?. Adalah: Buletin Hukum dan Keadilan, Vol. 4, No. 1.

Sari, S.A., Firdaus, M., Fadilla, N. A., Irsanti, R. 2019. Studi Pembuatan Sabun Cair dari Daging Buah Pepaya (Analisis Pengaruh Kadar Kalium Hidroksida terhadap Kualitas Sabun). TALENTA Conference Series. Vol. 2. No. 1. Hal : 60-67

Shinthia, Mega. 2016. Pembuatan sabun padat (rasio tallow - minyak kelapa minyak jagung). Politeknik Negeri Sriwijaya. eprints.polsri.ac.id

SNI. 1996. SNI 06-4085-1996. Sabun Mandi Cair. Jakarta: Dewan Standardisasi Nasional.

SNI. 2015. SNI 7431:2015. Mutu dan Metode Uji Minyak Nabati Murni untuk Bahan Bakar Motor Diesel Putaran Sedang. Jakarta: Dewan Standardisasi Nasional

Suhendra, D., Gunawan, E. R. 2010. Biodiesel from Ketapang Seeds: A New Green Energy. Proceeding of International Seminar on Economic, Culture and Environment. Mataram, Indonesia, pp. 68-76. 
Susetyo R., dan Reny H, 2004, Kiat Menghasilkan Minyak Sereh Wangi. Jakarta: Penebar Swadaya.

Tahrus, Z. N. 2020. Dunia dalam ancaman pandemi: Kajian transisi kesehatan dan mortalitas akibat Covid-19. Jakarta. Departemen Sosiologi, FISIP UI.

Warsito, Noorhamdani, Sukardi, Suratmo dan Susanti, R.D. 2017. Mikro enkapsulasi Minyak Jeruk Purut (Citrus Hystrix) dan Uji Aktivitasnya Sebagai Antibakteri. Journal of Environmental Engineering \& Sustainable Technology. Vol. 4, No. 1.

Warsito, Umi K., Edi P, U., Waode C, N. 2013. Preparasi komponenkomponen minyak jeruk purut (Citrus hystrix D.C.) sebagai bahan obat antimikroba dan antioksidan. Laporan Akhir Penelitian Unggulan Perguruan Tinggi, Lembaga Penelitian dan Pengabdian kepada Masyarakat. Universitas Brawijaya.

Wasitaatmadja, S. M. 2007. IImu Penyakit Kulit dan Kelamin. Edisi kelima,cetakan kedua, 3-8. Fakultas Kedokteran Universitas Indonesia: Jakarta.

WHO, 2020. https://covid19.who.int/WHO Coronavirus Disease (COVID-19) Dashboard. Data last updated: 2020/10/2, 5:04pm CEST.
Wibowo, D. P., Ardi, R., Yunan, K. 2016 Karakterisasi dan aktivitas repelen minyak atsiri sereh wangi (Cymbopogon nardus L), akar wangi (Vetiveria zizanoides L.), Nilam (pogestemon cablin), cengkeh (syzgium aromaticum) asal kabupaten garut terhadap nyamuk aedes aegypti betina. Jurnal Farmasi \& Farmasi Klinik. Vol. 13, No. 2.

Widyasanti, A dan Hasna A., H. 2016. Kajian pembuatan sabun padat transparan basis minyak kelapa murni dengan penambahan bahan aktif ekstrak teh putih. Jurnal Penelitian Teh dan Kina. 19(2): 179195.

Widyasanti, A., Chintya L. F., dan Dadan, R. 2016. Pembuatan Sabun Padat Transparan

Menggunakan Minyak Kelapa Sawit (Palm Oil) dengan Penambahan Bahan Aktif Ekstrak Teh Putih (Camellia sinensis). Jurnal Teknik Pertanian Lampung. Vol. 5, pp 125-136

Yang Z, Wu N, Zu Y, Fu Y. 2011. Comparative anti- infectious bronchitis virus (IBV) activity of betapinene: effect on nucleocapsid $(\mathrm{N})$ protein. Molecules. 16: 1044-1054. 